Article

\title{
An Unexpected Trinuclear Cobalt(II) Complex Based on a Half-Salamo-Like Ligand: Synthesis, Crystal Structure, Hirshfeld Surface Analysis, Antimicrobial and Fluorescent Properties
}

\author{
Ruo-Yan Li ${ }^{1,2}$, Xiao-Xin An ${ }^{3}$, Juan-Li Wu ${ }^{3}$, You-Peng Zhang ${ }^{1, *}$ and Wen-Kui Dong ${ }^{3, *}$ \\ 1 School of Automation and Electrical Engineering, Lanzhou Jiaotong University, Lanzhou 730070, China \\ 2 PetroChina Lanzhou Huanqiu Petrochemical Engineering Company, Lanzhou 730060, China \\ 3 School of Chemical and Biological Engineering, Lanzhou Jiaotong University, Lanzhou 730070, China \\ * Correspondence: zhangyp@mail.lzjtu.cn (Y.-P.Z.); dongwk@126.com (W.-K.D.); Tel.: +86-0931-4938-056 \\ (Y.-P.Z.); +86-0931-4938-703(W.-K.D.)
}

Received: 17 July 2019; Accepted: 2 August 2019; Published: 6 August 2019

\begin{abstract}
An unexpected trinuclear $\mathrm{Co}(\mathrm{II})$ complex, $\left[\mathrm{Co}_{3}\left(\mathrm{~L}^{2}\right)_{2}(\mu-\mathrm{OAc})_{2}\left(\mathrm{CH}_{3} \mathrm{OH}\right)_{2}\right] \cdot 2 \mathrm{CH}_{3} \mathrm{OH}\left(\mathrm{H}_{2} \mathrm{~L}^{2}=\right.$ 4,4'-dibromo-2,2' -[ethylenedioxybis(nitrilomethylidyne)]diphenol) constructed from a half-Salamo-based ligand $\left(\mathrm{HL}^{1}=2\right.$-[O-(1-ethyloxyamide)]oxime-4-bromophenol) and $\mathrm{Co}(\mathrm{OAc})_{2} \cdot 4 \mathrm{H}_{2} \mathrm{O}$, has been synthesized and characterized by elemental analyses, infrared spectra (IR), UV-Vis spectra, X-ray crystallography and Hirshfeld surface analysis. The Co(II) complex contains three Co(II) atoms, two completely deprotonated $\left(\mathrm{L}^{2}\right)^{2-}$ units, two bridged acetate molecules, two coordinated methanol molecules and two crystalline methanol molecules, and finally, a three-dimensional supramolecular structure with infinite extension was formed. Interestingly, during the formation of the Co(II) complex, the ligand changed from half-Salamo-like to a symmetrical single Salamo-like ligand due to the bonding interactions of the molecules. In addition, the antimicrobial activities of $\mathrm{HL}^{1}$ and its $\mathrm{Co}$ (II) complex were also investigated.
\end{abstract}

Keywords: half-salamo ligand; complex; crystal structure; Hirshfeld surface analysis; antimicrobial activity

\section{Introduction}

The Salen compound is a multifunctional tetradentate $\mathrm{N}_{2} \mathrm{O}_{2}$ chelating ligand in modern coordination chemistry and it is the most popular class of Schiff base ligands in this research field. Such ligands have multiple coordination sites and multiple selectivities to react with metal ions such as transition metal ions and rare earth metal ions [1,2]. Thus, a variety of complexes or polymers ranging from zero-dimensional to one-dimensional chain, two-dimensional and three-dimensional networks are obtained. As chemists continue to delve into the structures and properties of Salen-like metal complexes, the study of Salamo-like ligands and their complexes are also hot progress [3-10]. Therefore, such ligands and complexes have been successfully applied to functional materials [11-13], catalysts [14], biological fields [15-19], electrochemical research [20-23], magnetic materials [24-28], luminescences [29-38], ion recognitions [39-41], supramolecular buildings [42-46] and other fields, and have great prospects for their research.

A new trinuclear $\mathrm{Co}$ (II) complex based on a half-Salamo-like ligand was synthesized and characterized structurally by single crystal X-ray diffraction. Herein, during the reaction of the ligand $\mathrm{HL}^{1}$ with the $\mathrm{Co}$ (II) ions to form an unexpected complex, the Co(II) ions does not bind to the half-Salamo-like ligand $\mathrm{HL}^{1}$ that is intended to be designed. Instead, it combined with a newly formed symmetric Salamo-like ligand $\mathrm{H}_{2} \mathrm{~L}^{2}$ during the reaction to form an unexpected trinuclear $\mathrm{Co}$ (II) complex. It is worth mentioning that while studying the Hirshfeld surface analysis, the antibacterial activities were also studied. 


\section{Experimental}

\subsection{Materials and Measurements}

5-Bromo-2-hydroxybenzaldehyde ( $\geq 97.0 \%)$ was purchased from Meryer Chemical Technology Co., Ltd. (Shanghai, China). The other reagents and solvents were analytical grade reagents from Tianjin Chemical Reagent Factory and used as received. Melting points were measured by the use of a microscopic melting point apparatus made by the Beijing Taike Instrument Limited Company (Beijing, China) and the thermometer was uncorrected. Elemental analyses of metal element $(\mathrm{Co})$ and non-metallic elements $(\mathrm{C}, \mathrm{H}$, and N) were measured by an atomic emission spectrometer (IRIS ER/S.WP-1 ICP) and automatic elemental detection analyzer (GmbH VariuoEL V3.00) from Berlin, Germany, respectively. Fourier transform infrared (FT-IR) spectra were recorded on a VERTEX 70 FT-IR spectrophotometer with samples prepared as $\operatorname{KBr}\left(500-4000 \mathrm{~cm}^{-1}\right)$ from Bruker, Germany. UV-vis absorption spectra were measured on a UV-3900 spectrophotometer from Hitachi, Tokyo, Japan. Fluorescence spectra were recorded on a F-7000 FL 220-240V spectrophotometer from Hitachi, Tokyo, Japan. Hirshfeld surface analysis of the Co(II) complex was performed using the Crystal Explorer program [47]. X-ray single-crystal diffraction data was collected by a Bruker APEX-II CCD surface detecting diffractometer (Bruker, Germany), and Mo-K $\alpha$ ( $\lambda=0.71073$ $\AA$ ) ray radiation was monochromated with graphite.

\subsection{Synthesis of $H L^{1}$}

2-[O-(1-ethyloxyamide)]oxime-4-bromophenol $\left(\mathrm{HL}^{1}\right)$ was synthesized according to an analogous method reported earlier [48]. m.p.: $60-61{ }^{\circ} \mathrm{C} .{ }^{1} \mathrm{H} N \mathrm{NMR}\left(400 \mathrm{MHz}, \mathrm{CDCl}_{3}\right) \delta 3.95(\mathrm{t}, J=4.5 \mathrm{~Hz}, 2 \mathrm{H}), 4.36$ $(\mathrm{t}, J=4.5 \mathrm{~Hz}, 2 \mathrm{H}), 5.50(\mathrm{brs}, 2 \mathrm{H}), 6.87(\mathrm{~d}, J=9.0 \mathrm{~Hz}, 1 \mathrm{H}), 7.25(\mathrm{~d}, J=2.5 \mathrm{~Hz}, 1 \mathrm{H}), 7.37(\mathrm{dd}, J=9.0,2.5$ $\mathrm{Hz}, 1 \mathrm{H}), 8.14(\mathrm{~s}, 1 \mathrm{H}), 9.88(\mathrm{~s}, 1 \mathrm{H})$. IR (KBr, cm $\left.{ }^{-1}\right)$ : 3443 (s), 2993 (m), 2907 (m), 2815 (m), 1611 (s), 1492 (m), 1439 (s), $1393(\mathrm{~s}), 1360(\mathrm{~s}), 1320(\mathrm{~m}), 1181(\mathrm{~m}), 1036(\mathrm{~s}), 950(\mathrm{~s}), 897(\mathrm{w}), 778(\mathrm{~m}), 706(\mathrm{~m}), 665(\mathrm{w})$. UV-Vis $\left(\mathrm{CH}_{3} \mathrm{CH}_{2} \mathrm{OH}\right), \lambda_{\max }(\mathrm{nm})\left(\varepsilon_{\max }\right): 265$ and $322 \mathrm{~nm}\left(5.0 \times 10^{-5} \mathrm{M}\right)$. Anal. Calcd for $\mathrm{C}_{9} \mathrm{H}_{11} \mathrm{BrN}_{2} \mathrm{O}_{3}$ (\%): C 39.29; H 4.03; N 10.18. Found: C 39.58; H 4.00; N 10.01.

\subsection{Synthesis of the Co(II) Complex}

An anhydrous methanol solution $(2 \mathrm{~mL})$ of cobalt(II) acetate tetrahydrate $(4.98 \mathrm{mg}, 0.020 \mathrm{mmol})$ was added dropwise to a solution of $\mathrm{HL}^{1}(5.50 \mathrm{mg}, 0.020 \mathrm{mmol})$ in dichloromethane solution $(3 \mathrm{~mL})$, the mixed solution color changed to reddish brown instantly, and stirred for about 10-15 min, then filtered and sealed with foil paper. As the mixture solution gradually diffused, several brown bulk crystals were obtained after two weeks in open atmosphere. The main reaction process of the Co(II) complex is given in Scheme 1. IR (KBr, cm $\left.{ }^{-1}\right)$ : 3435 (s), 1605 (s), $1572(\mathrm{~m}), 1468(\mathrm{~s}), 1433(\mathrm{~m}), 1403(\mathrm{~m}), 1290(\mathrm{~m}), 1178(\mathrm{~m})$, $1088(\mathrm{w}), 1042(\mathrm{w}), 951(\mathrm{w}), 930(\mathrm{w}), 828(\mathrm{w}), 789(\mathrm{w}), 704(\mathrm{~m}), 646(\mathrm{w}), 531(\mathrm{w})$. UV-Vis $\left(\mathrm{CH}_{3} \mathrm{CH}_{2} \mathrm{OH}\right)$, $\lambda_{\max }(\mathrm{nm})\left(\varepsilon_{\max }\right): 372 \mathrm{~nm}\left(5.0 \times 10^{-5} \mathrm{M}\right)$. Anal. Calcd for $\left[\mathrm{Co}_{3}\left(\mathrm{~L}^{2}\right)_{2}(\mu-\mathrm{OAc})_{2}\left(\mathrm{CH}_{3} \mathrm{OH}\right)_{2}\right] \cdot 2 \mathrm{CH}_{3} \mathrm{OH}$ $\left(\mathrm{C}_{40} \mathrm{H}_{46} \mathrm{Br}_{4} \mathrm{Co}_{3} \mathrm{~N}_{4} \mathrm{O}_{16}\right)(\%): \mathrm{C} 35.98 ; \mathrm{H} 3.47 ; \mathrm{N}$ 4.20; Co 13.24. Found: $\mathrm{C} 36.12 ; \mathrm{H} 3.31 ; \mathrm{N}$ 4.11; Co 13.08.

\subsection{Crystal Structure of the Co(II) Complex}

X-ray single crystal diffraction data of the Co(II) complex was collected by a Bruker APEX-II CCD surface-detecting diffractometer, and monochromatic Mo-K $\alpha$ radiation $(\lambda=0.71073 \AA)$ was carried out with a graphite monochromator. The data was corrected with $\mathrm{Lp}$ factor and empirical absorption correction. The crystal structure was analyzed by the SHELXTL program, and all non-hydrogen atoms were found by direct-distribution and Fourier difference analysis. The structure was subjected to full matrix minimum multiplication correction through all non-hydrogen atoms. Table 1 summarizes the details of data collection and refinements of the Co(II) complex. The Crystallography Data Center in Cambridge collected crystallographic data as supplemental publications, No. CCDC 1939557 for the $\mathrm{Co}$ (II) complex. The data can be obtained free of charge from the Cambridge Crystallographic Data Centre and www.ccdc.cam.ac.uk/conts/retrieving.html. 

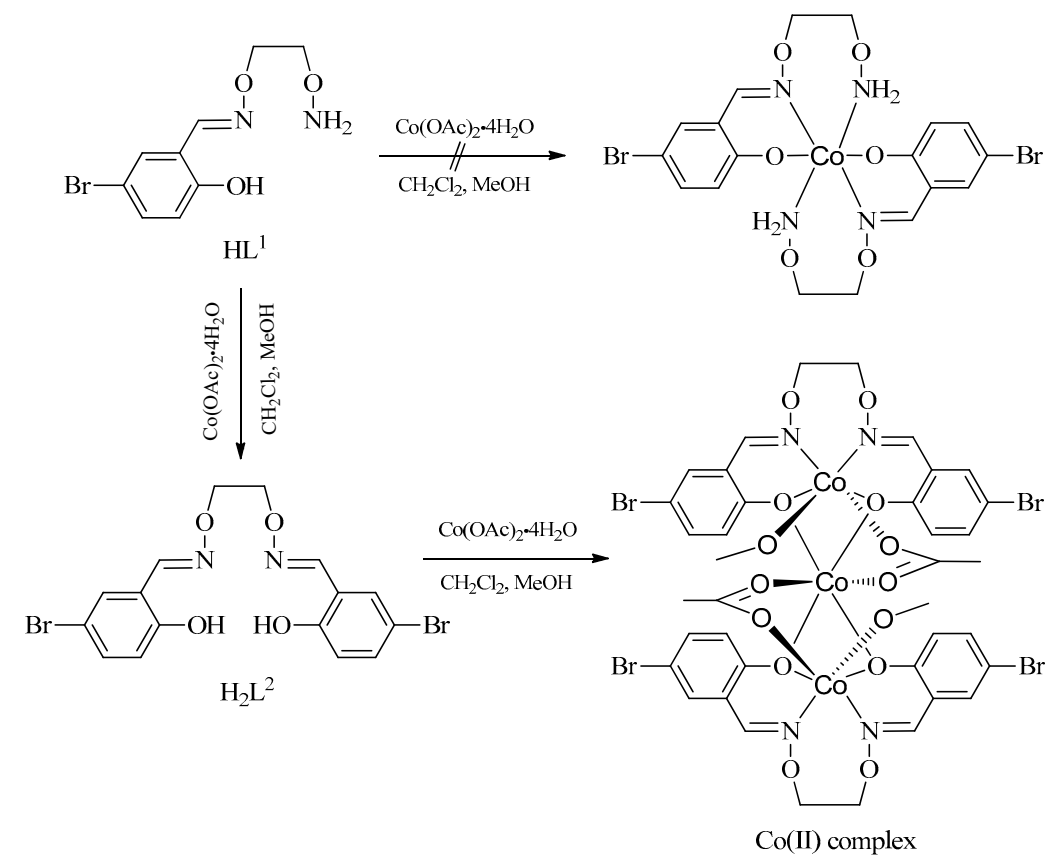

Scheme 1. Synthesis of the Co(II) complex.

Table 1. Crystal data for the Co(II) complex.

\begin{tabular}{|c|c|}
\hline Compound & The Co(II) Complex \\
\hline Formula & $\mathrm{C}_{40} \mathrm{H}_{46} \mathrm{Br}_{4} \mathrm{Co}_{3} \mathrm{~N}_{4} \mathrm{O}_{16}$ \\
\hline Formula weight & 1335.20 \\
\hline Temperature (K) & 173 \\
\hline Radiation $(\AA)$ & 0.71073 \\
\hline Crystal system & triclinic \\
\hline Space group & $P-1$ \\
\hline$a(\AA)$ & $10.9896(7)$ \\
\hline$b(\AA)$ & $11.0596(7)$ \\
\hline$c(\AA)$ & $11.2998(7)$ \\
\hline$\alpha\left({ }^{\circ}\right)$ & $99.760(2)$ \\
\hline$\beta\left({ }^{\circ}\right)$ & $94.287(2)$ \\
\hline$\gamma\left({ }^{\circ}\right)$ & 116.021(1) \\
\hline$V\left(\AA^{3}\right)$ & 1198.94(13) \\
\hline$Z$ & 1 \\
\hline$D_{\text {calc }}\left(\mathrm{g} \cdot \mathrm{cm}^{-3}\right)$ & 1.849 \\
\hline$\mu\left(\mathrm{mm}^{-1}\right)$ & 4.430 \\
\hline$F(000)$ & 663 \\
\hline Crystal size $(\mathrm{mm})$ & $0.17 \times 0.19 \times 0.22$ \\
\hline \multirow[t]{2}{*}{$\theta$ Range $\left(^{\circ}\right)$} & $2.18-25.01$ \\
\hline & $-13 \leq h \leq 13$ \\
\hline \multirow[t]{2}{*}{ Index ranges } & $-13 \leq k \leq 13$ \\
\hline & $-12 \leq l \leq 13$ \\
\hline Completeness to $\theta$ & $97.7 \%(\theta=25.01)$ \\
\hline Tot. Data & 8056 \\
\hline Uniq. Data & 4130 \\
\hline R (int) & 0.017 \\
\hline Observed Data & 3819 \\
\hline Nref/Npar & $4130 / 308$ \\
\hline GOF & 1.055 \\
\hline$R[I>2 \sigma(I)]$ & $R_{1}=0.0268, w R_{2}=0.0711$ \\
\hline Largest differences peak and hole $\left(\mathrm{e} \AA^{-3}\right)$ & $0.67 /-0.56$ \\
\hline
\end{tabular}




\section{Results and Discussion}

\subsection{IR Spectra}

In Figure 1, infrared spectra show different bands of $\mathrm{HL}^{1}$ and the $\mathrm{Co}(\mathrm{II})$ complex in the range of $500-4000 \mathrm{~cm}^{-1}$. The $\mathrm{O}-\mathrm{H}$ stretching frequency of $\mathrm{HL}^{1}$ appears at $3443 \mathrm{~cm}^{-1}$, and the peak of the $\mathrm{Co}$ (II) complex moves to lower frequency, which occurs at about $3435 \mathrm{~cm}^{-1}$. The $\mathrm{O}-\mathrm{H}$ stretching vibration is caused by the presence of crystalline methanol molecules in the Co(II) complex. The ligand $\mathrm{HL}^{1}$ shows a characteristic $C=N$ stretching band at $1611 \mathrm{~cm}^{-1}$, while the $C=N$ stretching band of the $C o$ (II) complex appears at $1605 \mathrm{~cm}^{-1}$. At the same time, the free ligand $\mathrm{HL}^{1}$ exhibits an Ar-O stretching frequency at $1181 \mathrm{~cm}^{-1}$, and that of the $\mathrm{Co}$ (II) complex appears at $1178 \mathrm{~cm}^{-1}$, and the Ar-O stretching frequency moving to low frequencies, indicating the formations of $\mathrm{Co}(\mathrm{II})-\mathrm{O}$ bonds.

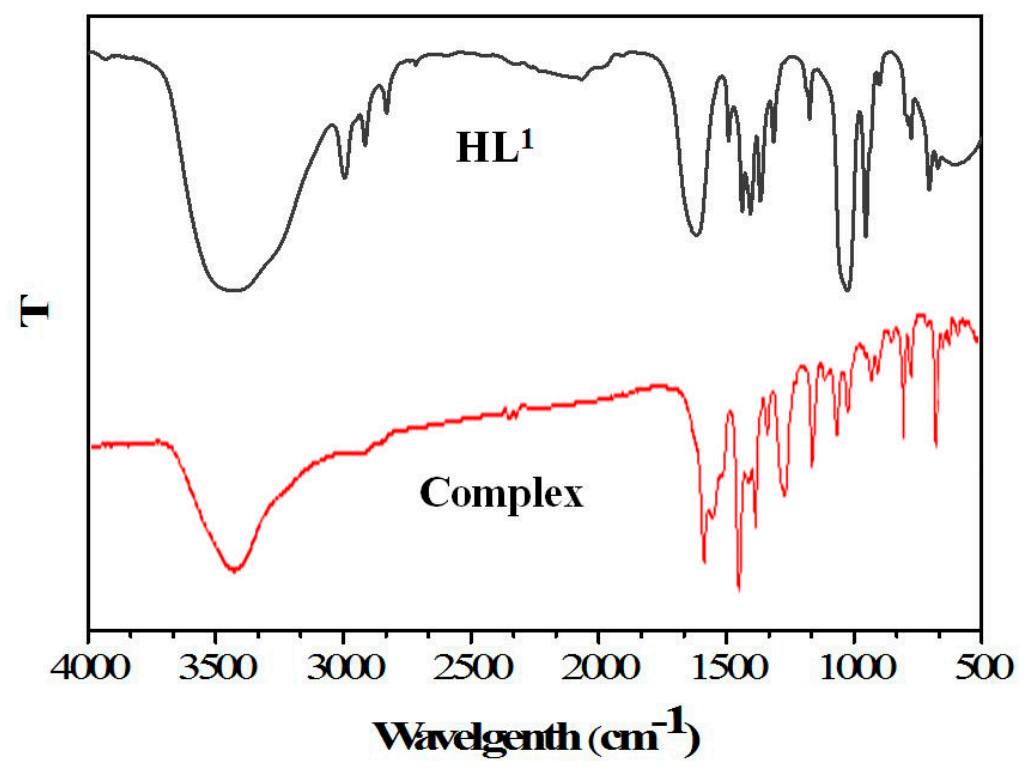

Figure 1. IR spectra of $\mathrm{HL}^{1}$ and the Co(II) complex.

\subsection{UV-Vis Spectra}

The UV-visible absorption spectra of $\mathrm{HL}^{1}$ and the $\mathrm{Co}(\mathrm{II})$ complex $\left(5.0 \times 10^{-5} \mathrm{M}\right.$, ethanol solution) were determined by UV-VIS spectrophotometer, as shown in Figure 2. It is obvious that the absorption peak of the $\mathrm{Co}$ (II) complex is significantly different from that of $\mathrm{HL}^{1}$. We can easily find out that the free ligand $\mathrm{HL}^{1}$ exhibits two characteristic absorption peaks at 265 and $322 \mathrm{~nm}$, which can be attributed to the $\pi-\pi^{*}$ transitions [49]. The corresponding absorption peak of the Co(II) complex appear at $372 \mathrm{~nm}$ compared to the absorption peaks of the free ligand $\mathrm{HL}^{1}$. The absorption at $372 \mathrm{~nm}$ can be attributed to the $n-\pi^{*}$ charge transfer transition from the filled $p-\pi$ orbital of the phenolic oxygen to the empty $d$ orbital of the $\mathrm{Co}$ (II) ions, and indicates that the $\mathrm{Co}$ (II) ions and the ligand are successfully coordinated. In the UV-Vis titration experiment of the Co(II) complex, the absorbance at 265 and 322 nm gradually decreased and disappeared with the increase of $\mathrm{Co}^{2+}$ concentration $\left(1.0 \times 10^{-4} \mathrm{M}\right.$, aqueous solution), while at $372 \mathrm{~nm}$, a new absorption peak appears. This is a characteristic of Salamo-like complexes. When $\mathrm{Co}^{2+}$ was added to 1.5 equivalents, the absorption peak reaches the highest value. Spectral titration indicates that the ratio of displacement reaction was $1: 1.5\left(\left(\mathrm{~L}^{1}\right)^{-}: \mathrm{Co}^{2+}\right)$ (Figure 3 ). 


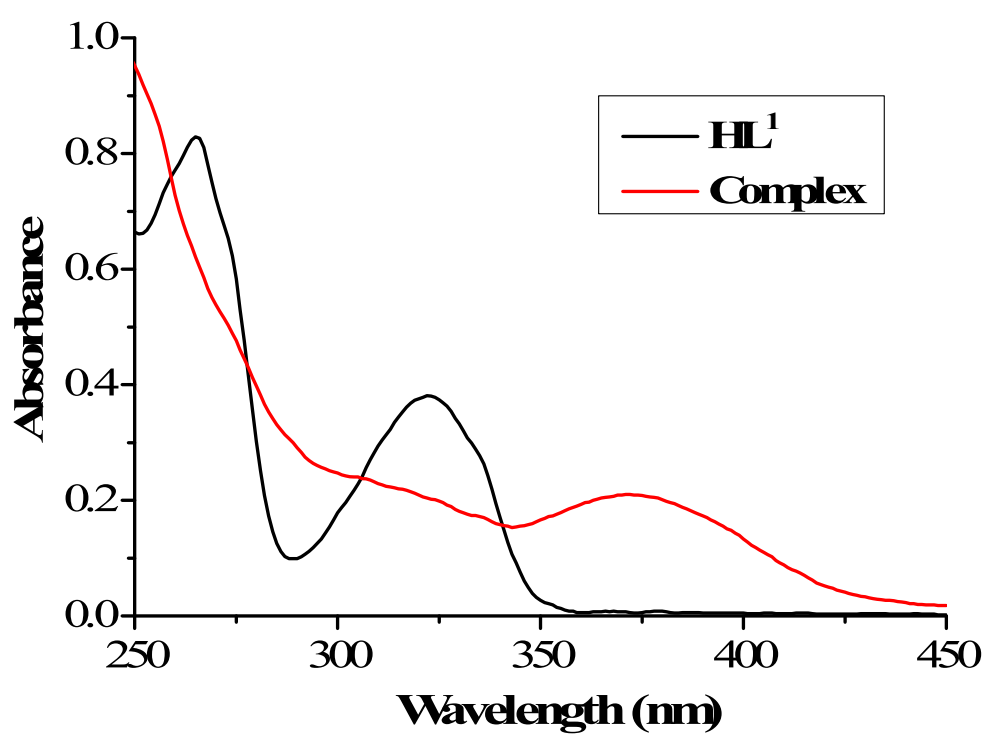

Figure 2. The UV-Vis spectra of $\mathrm{HL}^{1}$ and the $\mathrm{Co}(\mathrm{II})$ complex.

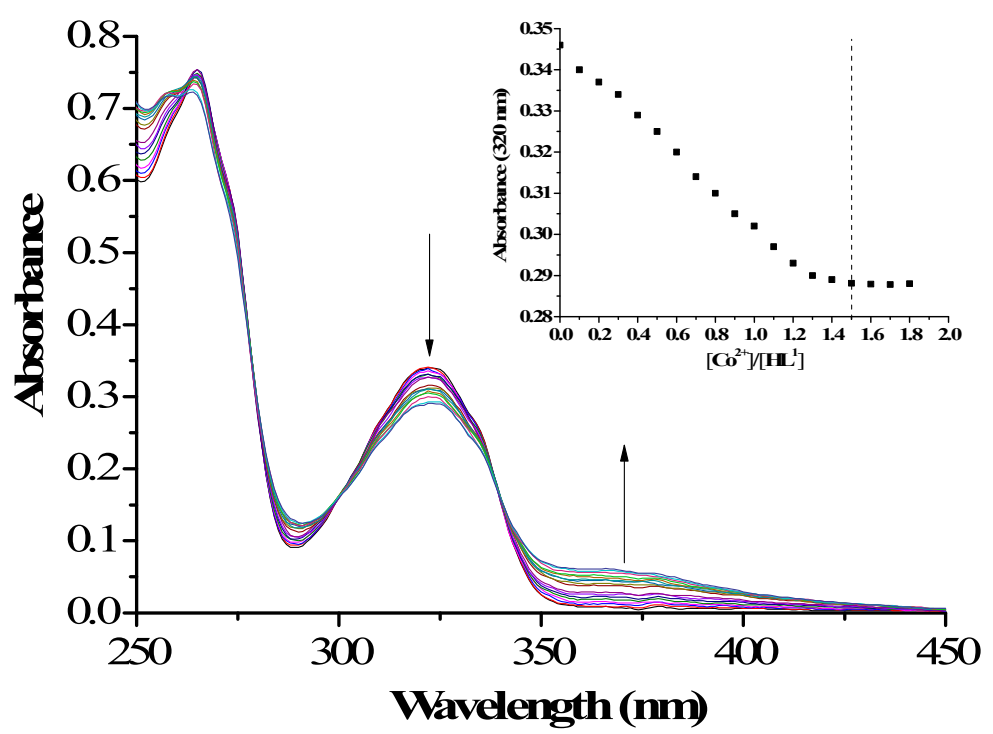

Figure 3. Ultra violet (UV)-Vis spectra of the changes in $\mathrm{HL}^{1}$ upon addition of $\mathrm{Co}(\mathrm{OAc})_{2} \cdot 4 \mathrm{H}_{2} \mathrm{O}$ (Inset: the absorbance at $320 \mathrm{~nm}$ varies with the interaction of $\left.\left[\mathrm{Co}^{2+}\right] /\left[\mathrm{HL}^{1}\right]\right)$.

\subsection{Description of the Crystal Structure}

The crystal structure of the Co(II) complex and coordination polyhedral map of Co(II) atoms of the Co(II) complex are shown in Figure 4, and the selected bond lengths and angles are given in Table 2. The X-ray crystal structure of the $\mathrm{Co}$ (II) complex shows that it crystallizes in the $P$ - 1 space group of the triclinic system, in which the $\mathrm{Co}$ (II) atoms are all in a twisted octahedral geometry. It is worth noting that a new symmetrical Salamo-like-based $\mathrm{Co}(\mathrm{II})$ complex $\left[\mathrm{Co}_{3}\left(\mathrm{~L}^{2}\right)_{2}(\mu-\mathrm{OAc})_{2}\left(\mathrm{CH}_{3} \mathrm{OH}\right)_{2}\right] \cdot 2 \mathrm{CH}_{3} \mathrm{OH}$ was obtained instead of the half-Salamo-like $\mathrm{Co}$ (II) complex expected in advance. The results show that due to the catalysis of $\mathrm{Co}$ (II) ions [50,51], complexation leads to a $\mathrm{N}-\mathrm{O}$ bond cleavage in $\mathrm{HL}^{1}$ (make the $\mathrm{N}-\mathrm{O}-\mathrm{N}$ cavity disappear), resulting in a new symmetric $\mathrm{N}_{2} \mathrm{O}_{2}$ tetradentate ligand $\mathrm{H}_{2} \mathrm{~L}^{2}$, which coordinates with $\mathrm{Co}(\mathrm{II})$ ions and forms a homo-trinuclear $\mathrm{Co}$ (II) complex. So actually, the unexpected trinuclear $\mathrm{Co}(\mathrm{II})$ complex $\left[\mathrm{Co}_{3}\left(\mathrm{~L}^{2}\right)_{2}(\mu-\mathrm{OAc})_{2}\left(\mathrm{CH}_{3} \mathrm{OH}\right)_{2}\right] \cdot 2 \mathrm{CH}_{3} \mathrm{OH}$ was formed by coordination of $\mathrm{H}_{2} \mathrm{~L}^{2}$ with $\mathrm{Co}(\mathrm{OAc})_{2} \cdot 4 \mathrm{H}_{2} \mathrm{O}$, the molecular structure of the $\mathrm{Co}(\mathrm{II})$ complex consists of three $\mathrm{Co}(\mathrm{II})$ atoms and two completely deprotonated ligand $\left(\mathrm{L}^{2}\right)^{2-}$ units. 


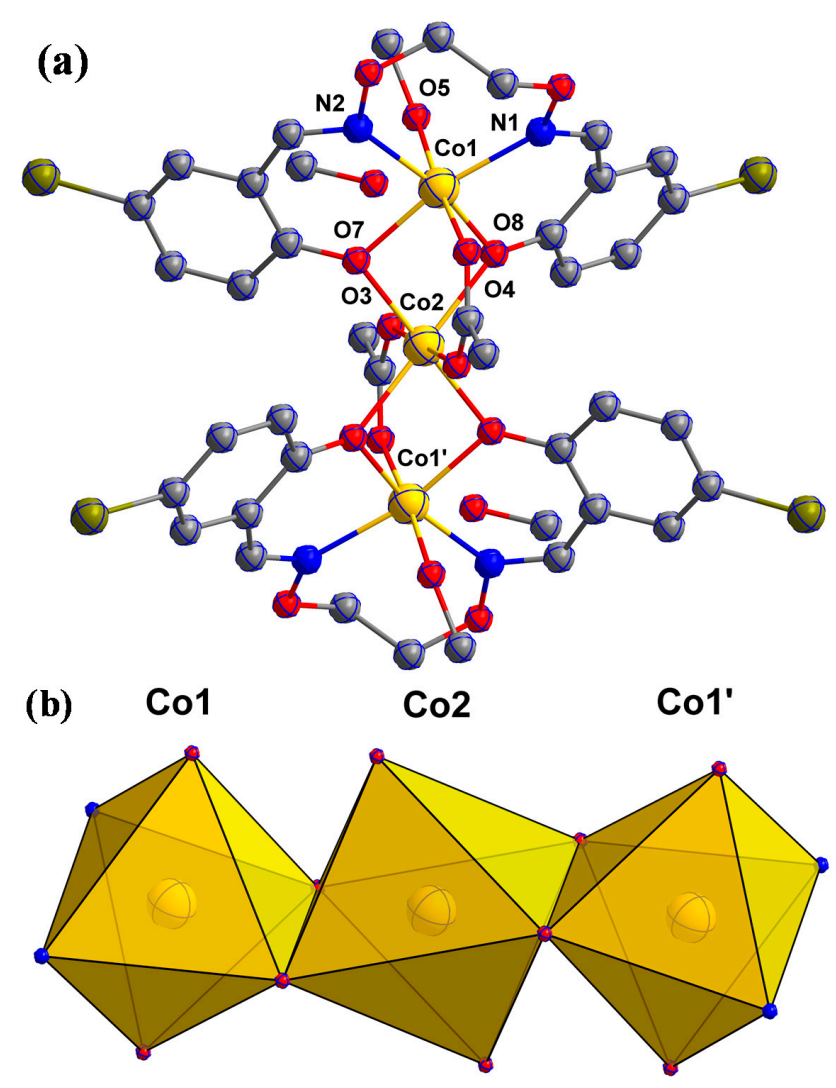

Figure 4. (a) The crystal structure of the Co(II) complex (hydrogen atoms are omitted for clarity, and the atomic symbol only marked the symmetrical part); (b) Coordination polyhedral map of Co(II) atoms.

Table 2. Bond lengths $(\AA)$ and angles $\left(^{\circ}\right)$ of the Co(II) complex.

\begin{tabular}{|c|c|c|c|}
\hline Bond & Lengths & Bond & Lengths \\
\hline Co1-O4 & $2.058(2)$ & Co2-O3 & $2.1243(19)$ \\
\hline Co1-O5 & $2.114(2)$ & $\mathrm{Co} 2-\mathrm{O} 7$ & $2.1109(18)$ \\
\hline Co1-O7 & $2.063(2)$ & $\mathrm{Co} 2-\mathrm{O} 8$ & $2.104(2)$ \\
\hline Co1-O8 & $2.0538(18)$ & $\mathrm{Co} 2-\mathrm{O} 3{ }^{\# 1}$ & $2.1243(19)$ \\
\hline Co1-N1 & $2.131(2)$ & $\mathrm{Co} 2-\mathrm{O} 7^{\# 1}$ & $2.1109(18)$ \\
\hline Co1-N2 & $2.127(2)$ & $\mathrm{Co} 2-\mathrm{O} 8{ }^{\# 1}$ & $2.104(2)$ \\
\hline Bond & Angles & Bond & Angles \\
\hline O4-Co1-O5 & $176.02(9)$ & O3-Co2-O7 & $86.91(7)$ \\
\hline $\mathrm{O} 4-\mathrm{Co} 1-\mathrm{O} 7$ & $91.12(8)$ & $\mathrm{O} 3-\mathrm{Co} 2-\mathrm{O} 8$ & $88.95(8)$ \\
\hline O4-Co1-O8 & $93.46(8)$ & $\mathrm{O} 3-\mathrm{Co} 2-\mathrm{O} 3{ }^{\# 1}$ & 180.00 \\
\hline O4-Co1-N1 & $86.33(9)$ & O3-Co2-O7 \#1 & $93.09(7)$ \\
\hline O4-Co1-N2 & $93.12(8)$ & $\mathrm{O} 3-\mathrm{Co} 2-\mathrm{O} 8{ }^{\# 1}$ & $91.06(8)$ \\
\hline O5-Co1-O7 & $92.86(8)$ & $\mathrm{O} 7-\mathrm{Co} 2-\mathrm{O} 8$ & $77.29(7)$ \\
\hline O5-Co1-O8 & $87.06(8)$ & $\mathrm{O} 3{ }^{\# 1-C o} 2-\mathrm{O} 7$ & $93.09(7)$ \\
\hline O5-Co1-N1 & $89.75(9)$ & O7-Co2-O7 \#1 & 180.00 \\
\hline O5-Co1-N2 & $87.29(8)$ & $\mathrm{O} 7-\mathrm{Co} 2-\mathrm{O} 8^{\# 1}$ & $102.71(7)$ \\
\hline O7-Co1-O8 & $79.48(8)$ & $\mathrm{O} 3^{\# 1-C o 2-O 8}$ & $91.06(8)$ \\
\hline O7-Co1-N1 & $166.34(8)$ & $\mathrm{O} 7^{\# 1-C o 2-O 8}$ & $102.71(7)$ \\
\hline O7-Co1-N2 & $87.42(8)$ & $\mathrm{O} 8-\mathrm{Co} 2-\mathrm{O} 8^{\# 1}$ & 180.00 \\
\hline O8-Co1-N1 & $87.27(9)$ & $\mathrm{O} 3^{\# 1-C o 2-O 7^{\# 1}}$ & $86.91(7)$ \\
\hline O8-Co1-N2 & $165.44(9)$ & $\mathrm{O} 3^{\# 1-C o 2-O 8}{ }^{\# 1}$ & $88.95(8)$ \\
\hline N1-Co1-N2 & 106.11(9) & $\mathrm{O} 7^{\# 1}-\mathrm{Co} 2-\mathrm{O} 8{ }^{\# 1}$ & $77.29(7)$ \\
\hline
\end{tabular}

Symmetry transformations used to generate equivalent atoms: ${ }^{\# 1} 1-x, 1-y, 1-z$.

The corresponding hydrogen bonds of the Co(II) complex are summarized in Table 3 . As illustrated

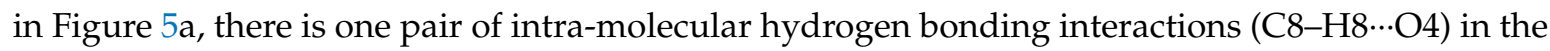
$\mathrm{Co}$ (II) complex [52], In addition, inter-molecular hydrogen bonding interactions are shown in Figure 5b, 
and three pairs of intermolecular hydrogen bond interactions were formed in the Co(II) complex, which was $\mathrm{O} 5-\mathrm{H} 5 \mathrm{~F} \cdots \mathrm{O} 6, \mathrm{O} 6-\mathrm{H} 6 \cdots \mathrm{O} 3$ and $\mathrm{C} 14-\mathrm{H} 14 \cdots \mathrm{O} 1$, respectively. Hydrogen bonding interactions play a significant role in the construction of the Co(II) complex. Therefore, an infinite 3-D supramolecular structure is finally formed (Figure 5c).

Table 3. Hydrogen bonding interactions $\left(\AA,^{\circ}\right)$ of the Co(II) complex.

\begin{tabular}{|c|c|c|c|c|c|}
\hline D-H $\cdots A$ & $d(D-H)$ & $\mathrm{d}(\mathrm{H} \cdots \mathrm{A})$ & $d(D \cdots A)$ & $\angle \mathrm{D}-\mathrm{H} \cdots \mathbf{A}$ & Symmetry Code \\
\hline O5-H5F …66 & 0.91 & 1.70 & $2.611(3)$ & 175 & \\
\hline $\mathrm{C} 6-\mathrm{H} 6 \cdots \mathrm{O} 3$ & 0.84 & 1.83 & $2.666(3)$ & 176 & $1-x, 1-y, 1-z$ \\
\hline $\mathrm{C} 8-\mathrm{H} 8 \mathrm{~B} \cdots \mathrm{O} 4$ & 0.99 & 2.36 & $3.212(4)$ & 143 & \\
\hline C14-H14‥O1 & 0.95 & 2.60 & $3.307(4)$ & 132 & $1+x, y, z$ \\
\hline
\end{tabular}
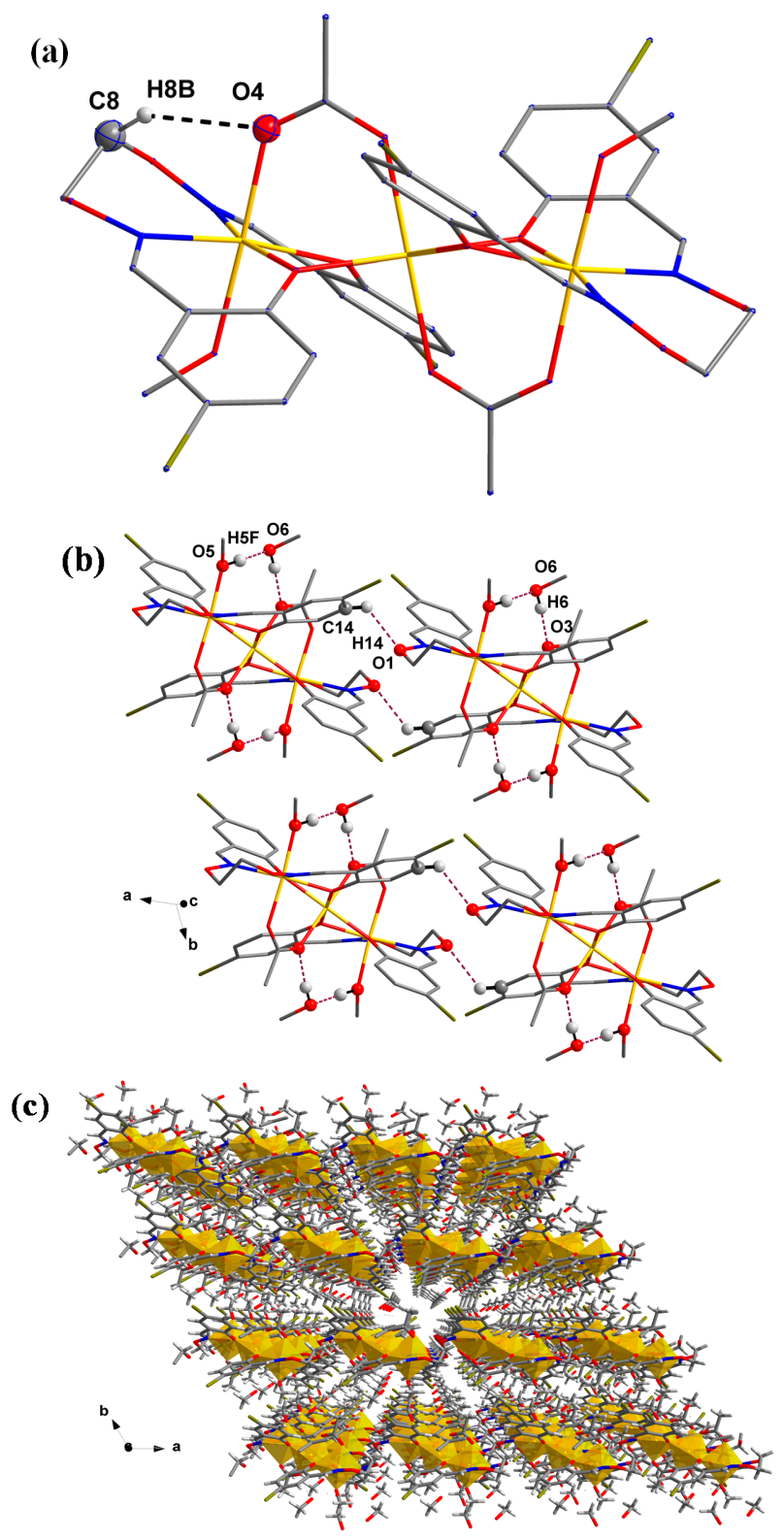

Figure 5. View of the hydrogen bonding interactions of the Co(II) complex (hydrogen atoms are omitted for clarity, except those forming hydrogen bondings): (a) Intra-molecular hydrogen bonding interaction; (b) Inter-molecular hydrogen bonding interactions; (c) 3-D supra-molecular structure. 


\subsection{Fluorescence Spectra}

The fluorescent properties of the ligand $\mathrm{HL}^{1}$ and the $\mathrm{Co}$ (II) complex in ethanol solvent are shown in Figure 6. The concentration of the ligand $\mathrm{HL}^{1}$ and the $\mathrm{Co}(\mathrm{II})$ complex was $5.0 \times 10^{-5} \mathrm{M}$. At room temperature, at $320 \mathrm{~nm}$ excitation, the free ligand $\mathrm{HL}^{1}$ shows a relatively strong emission peak at $367 \mathrm{~nm}$ and should be assigned to the ligand $\pi-\pi^{*}$ transition. Compared with the free ligand $\mathrm{HL}^{1}$, a weak fluorescence intensity at $360 \mathrm{~nm}$ was observed in the Co(II) complex, indicating that the fluorescence characteristics were affected by the introduction of Co(II) ions, as a result, the fluorescence intensity gradually weakens during the process from the ligand $\mathrm{HL}^{1}$ to the $\mathrm{Co}(\mathrm{II})$ complex. These transitions may be related to the coordination of the ligand $\mathrm{HL}^{1}$ and the $\mathrm{Co}(\mathrm{II})$ ions, which allows the ligand to develop towards a more stable complex.

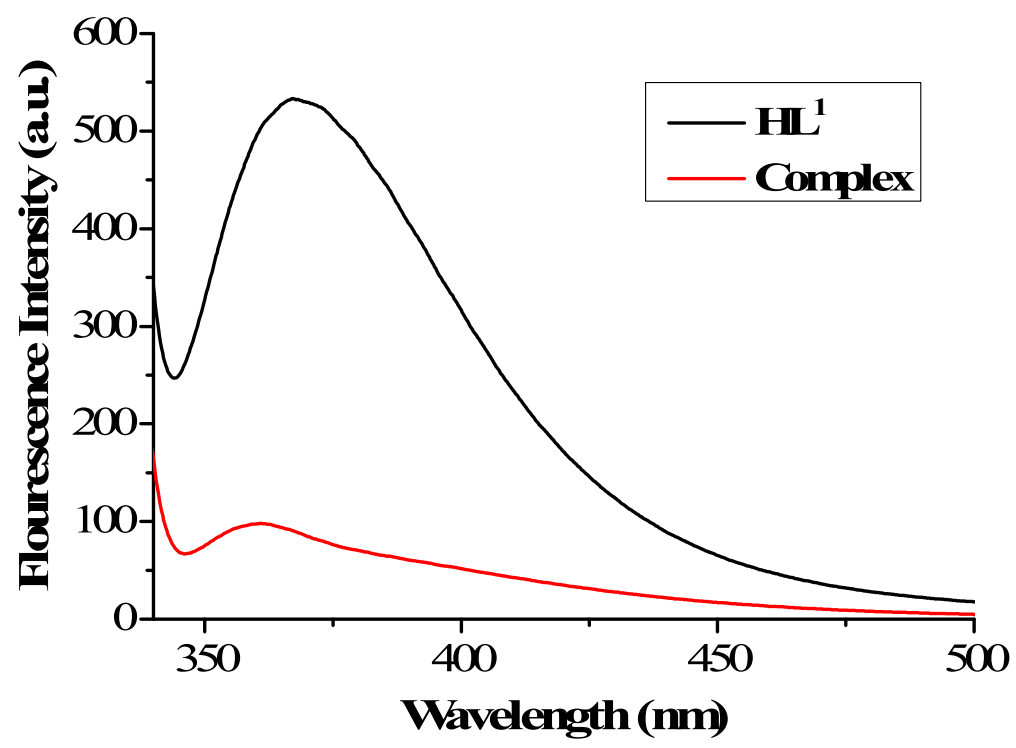

Figure 6. Fluorescence spectra of $\mathrm{HL}^{1}$ and the $\mathrm{Co}(\mathrm{II})$ complex upon excitation at $320 \mathrm{~nm}$ (ethanol, $5.0 \times 10^{-5} \mathrm{M}$ ).

\subsection{Hirshfeld Surface Analysis}

Hirshfeld surface analysis and 2D finger-printing of the Co(II) complex were performed using the Crystal Explorer program [47]. This figure can visually show the weak interactions in the molecular crystal. The electron density of the red region is relatively high because of the formation of hydrogen bonds, and the electron density of the blue region is small and there is no obvious interaction. As shown in Figure 7, the Hirshfeld surface distribution was performed on the Co(II) complex by Curvedness, Shape-Index, $d_{\text {norm }}, d_{\mathrm{e}}$ and $d_{\mathrm{i}}$ mapping.

The short-range interaction distribution inside the Co(II) complex was calculated by Hirshfeld fingerprint plot to quantify the intermolecular interaction. The 2-D fingerprint is summarized in Figure 8. As shown in the figure, for each molecule of the $\mathrm{Co}(\mathrm{II})$ complex, the proportion of $\mathrm{C}-\mathrm{H} / \mathrm{H}-\mathrm{C}$, $\mathrm{O}-\mathrm{H} / \mathrm{H}-\mathrm{O}, \mathrm{H}-\mathrm{H} / \mathrm{H}-\mathrm{H}$ and $\mathrm{Br}-\mathrm{H} / \mathrm{H}-\mathrm{Br}$ interactions was $9.8 \%, 5.7 \%, 40.7 \%$ and $13.6 \%$ of the total Hirshfeld surface, respectively. It is apparent that the intermolecular interactions of the total surface of Hirshfeld are mainly derived from the $\mathrm{H}-\mathrm{H} / \mathrm{H}-\mathrm{H}$ interaction. 


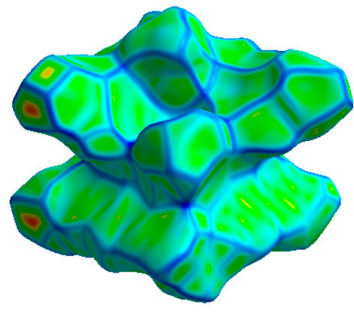

(a)

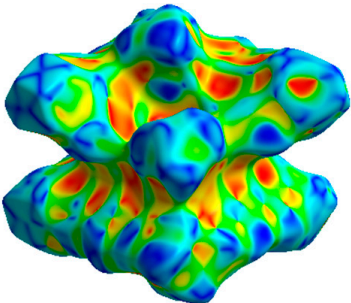

(b)

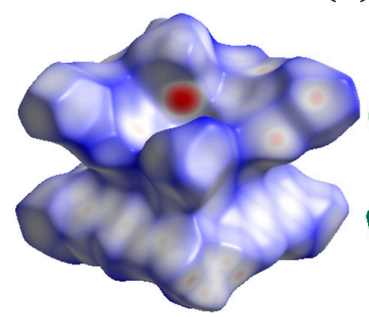

(c)

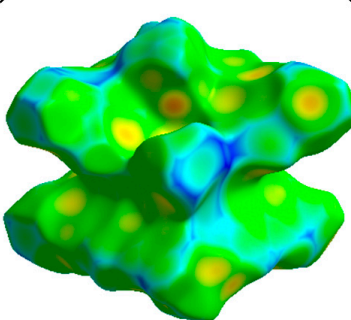

(d)

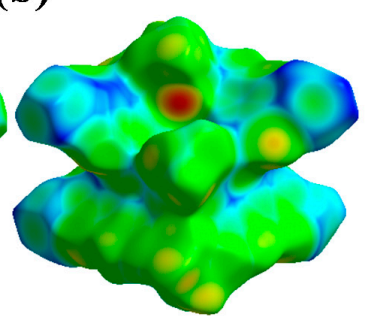

(e)

Figure 7. Hirshfeld surface analysis of the Co(II) complex: (a) Curvedness; (b) Shape-Index; (c) $d_{\text {norm }}$; (d) $d_{\mathrm{e}} ;(\mathbf{e}) d_{\mathrm{i}}$.
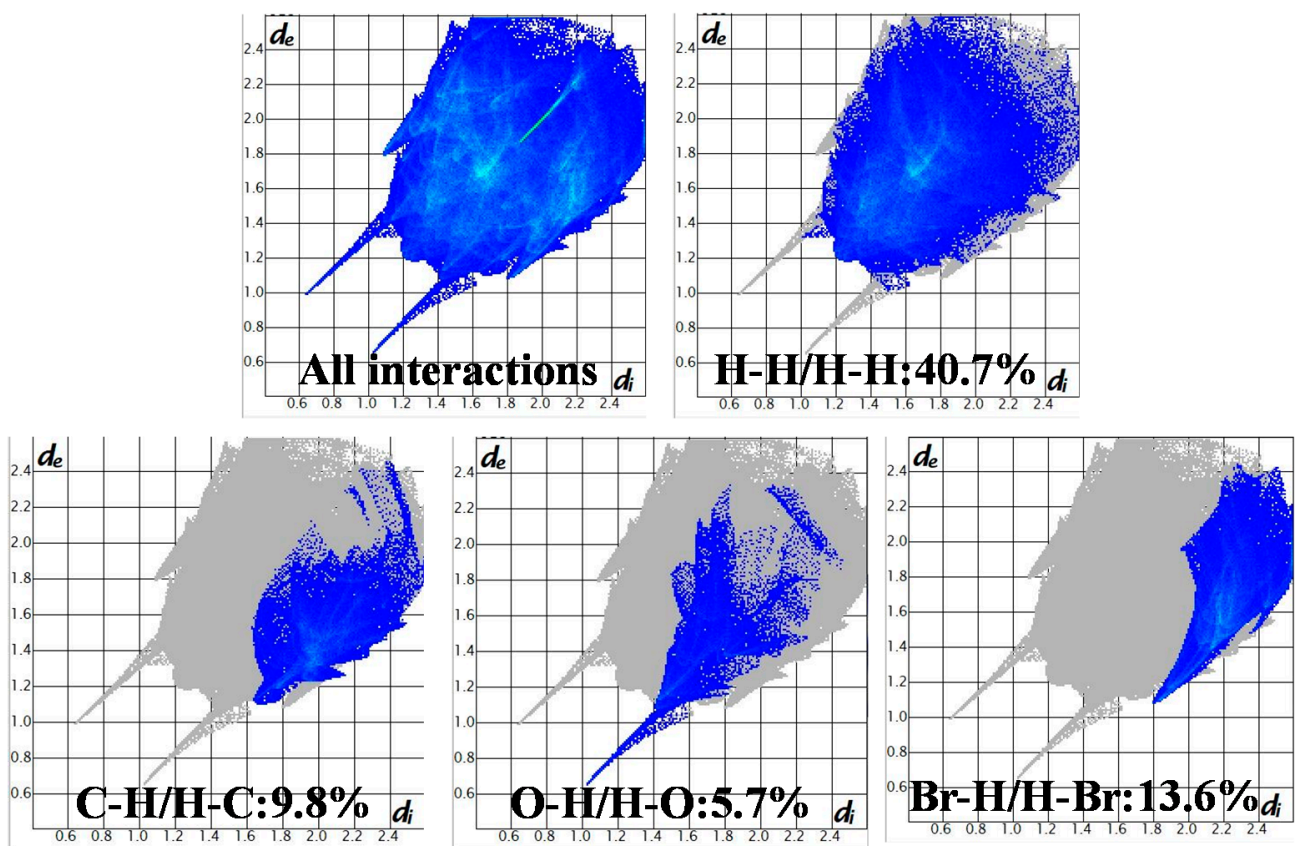

Figure 8. Finger-print plot of percentages of contacts on the Hirshfeld surface in the Co(II) complex.

\subsection{Antibacterial Activities}

The antibacterial activities of $\mathrm{HL}^{1}$, cobalt(II) acetate tetrahydrates and the $\mathrm{Co}(\mathrm{II})$ complex were tested by perforation method, and Gram-negative Escherichia coli was selected as the research object. First, the $\mathrm{Co}(\mathrm{II})$ complex is formulated into a solution of the same concentration using different solvents (DMF, DMSO, TCM, DCM, MeOH, EtOH, PA, ACN), and secondly, when culturing E. coli to $\mathrm{OD} 600 \approx 1.0$ using LB liquid medium ( $\%$ agar), add $25 \mu \mathrm{L}$ to LB solid medium at about $50{ }^{\circ} \mathrm{C}$, pour the plate to solidify, and punch with a puncher. A sample of $200 \mu \mathrm{L}$ of different solvent was added to each well and placed in an LRH-250-G light incubator at $37^{\circ} \mathrm{C}$ for $12 \mathrm{~h}$ to observe the size of the zone of inhibition. As shown in Figure 9a, only the DMF has a larger diameter of the inhibition ring than other solvents, indicating that the complex has relatively strong antibacterial activity in the presence of DMF. 

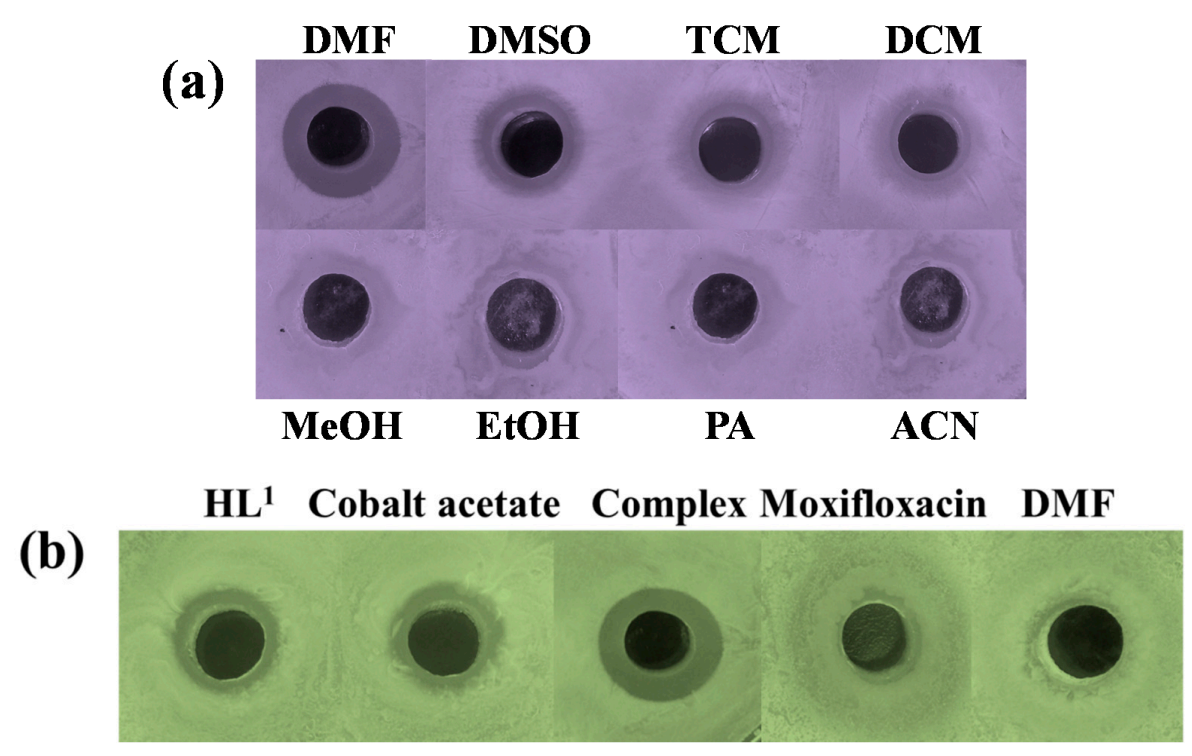

Figure 9. (a) The diameter of the inhibition zone of Escherichia coli in different solvents of the Co(II) complex; (b) The diameter of the inhibition zone of Escherichia coli in different samples at a concentration of $3.2 \mathrm{mg} / \mathrm{mL}$.

Four groups of solutions were prepared by DMF solution at concentrations of $0.4 \mathrm{mg} / \mathrm{mL}$, $0.8 \mathrm{mg} / \mathrm{mL}, 1.6 \mathrm{mg} / \mathrm{mL}$, and $3.2 \mathrm{mg} / \mathrm{mL}$, respectively. Under the same conditions, using moxifloxacin as a positive control experiment, $200 \mu \mathrm{L}$ of the sample was added to the LB solid medium, and all the samples were incubated at a constant temperature of $32{ }^{\circ} \mathrm{C}$ for $12 \mathrm{~h}$, and Figure $9 \mathrm{~b}$ is a zone of inhibition of a different sample at a concentration of $3.2 \mathrm{mg} / \mathrm{mL}$, we can clearly see that the diameter of the inhibition zone of $\mathrm{HL}^{1}$, cobalt acetate, the Co(II) complex and moxifloxacin increased sequentially. From the results of Figure 10, it can be shown that the Co(II) complex has stronger antibacterial activity than the ligand, and the antibacterial activity increases as the concentration increases.

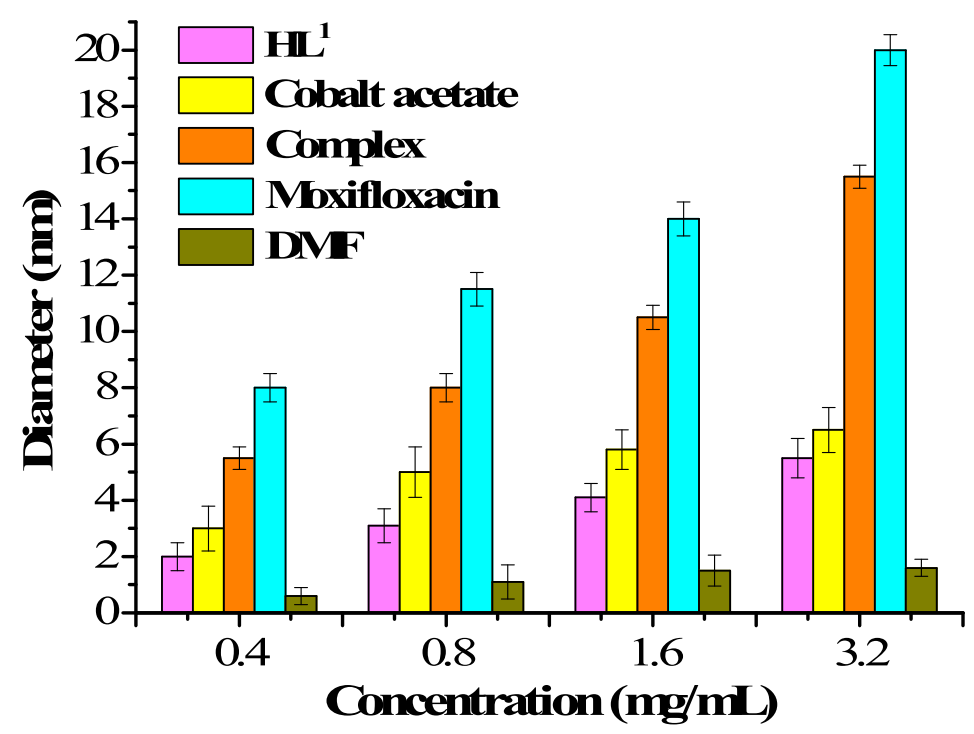

Figure 10. A histogram of the inhibition zone diameter of Escherichia coli at different concentrations of different samples.

\section{Conclusions}

An unexpected supramolecular $\mathrm{Co}(\mathrm{II})$ complex $\left[\mathrm{Co}_{3}\left(\mathrm{~L}^{2}\right)_{2}(\mu-\mathrm{OAc})_{2}\left(\mathrm{CH}_{3} \mathrm{OH}\right)_{2}\right] \cdot 2 \mathrm{CH}_{3} \mathrm{OH}$ was synthesized and characterized by physicochemical methods and single crystal X-ray diffraction. 
The results show that each $\mathrm{Co}(\mathrm{II})$ atoms is hexa-coordinated, and it forms three structurally stable octahedrons with $\mathrm{O}$ and $\mathrm{N}$ atoms of coordinated methanol molecules, bridged acetate molecules and the completely deprotonated $\left(\mathrm{L}^{2}\right)^{2-}$ moities. Each molecule of the Co(II) complex is linked to each other to form a three-dimensional supra-molecular network. This kind of complex has potential applications and deserves further study and can be used to develop novel transition metal complexes.

Author Contributions: W.-K.D. conceived and designed the experiments, and contributed reagents/materials/ analysis tools; X.-X.A., R.-Y.L. and J.-L.W. performed the experiments; Y.-P.Z. analyzed the data; R.-Y.L. and X.-X.A. wrote the paper.

Funding: This work was supported by the National Natural Science Foundation of China(Grant No. 21761018), and the Program for Excellent Team of Scientific Research in Lanzhou Jiaotong University(Grant No. 201706).

Conflicts of Interest: The authors declare no competing financial interests.

\section{References}

1. Liu, X.; Manzurc, C.; Novoa, N.; Celedónc, S.; Carrilloc, D.; Hamon, J.R. Multidentate unsymmetricallysubstituted Schiff bases and their metal complexes: Synthesis, functional materials properties, and applications to catalysis. Coord. Chem. Rev. 2018, 357, 144-172. [CrossRef]

2. Liu, X. Recent developments in penta-, hexa- and heptadentate Schiff base ligands and their metal complexes. Coord. Chem. Rev. 2019, 389, 94-118. [CrossRef]

3. Li, X.Y.; Kang, Q.P.; Liu, L.Z.; Ma, J.C.; Dong, W.K. Trinuclear Co(II) and mononuclear Ni(II) salamo-type bisoxime coordination compounds. Crystals 2018, 8, 43. [CrossRef]

4. Zhang, L.W.; Liu, L.Z.; Wang, F.; Dong, W.K. Unprecedented fluorescent dinuclear Co ${ }^{\mathrm{II}}$ and $\mathrm{Zn}^{\mathrm{II}}$ coordination compounds with a symmetric bis(salamo)-like tetraoxime. Molecules 2018, 23, 1141. [CrossRef]

5. Akine, S.; Sairenji, S.; Taniguchi, T.; Nabeshima, T. Stepwise helicity inversions by multisequential metal Exchange. J. Am. Chem. Soc. 2013, 135, 12948-12951. [CrossRef]

6. Wang, P.; Zhao, L. Synthesis, structure and spectroscopic properties of the trinuclear cobalt(II) and nickel(II) complexes based on 2-hydroxynaphthaldehyde and bis(aminooxy)alkane. Spectrochim. Acta A 2015, 135, 342-350. [CrossRef]

7. Akine, S.; Tadokoro, T.; Nabeshima, T. Oligometallic template strategy for synthesis of a macrocyclic dimer-type octaoxime ligand for its cooperative complexation. Inorg. Chem. 2012, 51, 11478-11486. [CrossRef]

8. Akine, S.; Varadi, Z.; Nabeshima, T. Synthesis of planar metal complexes and the stacking abilities of naphthalenediol-based acyclic and macrocyclic salen-type ligands. Eur. J. Inorg. Chem. 2013, 2013, 5987-5998. [CrossRef]

9. Akine, S.; Kagiyama, S.; Nabeshima, T. Modulation of multimetal complexation behavior of tetraoxime ligand by covalent transformation of olefinic functionalities. Inorg. Chem. 2010, 49, 2141-2152. [CrossRef]

10. Wang, F.; Liu, L.Z.; Gao, L.; Dong, W.K. Unusual constructions of two salamo-based copper(II) complexes. Spectrochim. Acta A 2018, 203, 56-64. [CrossRef]

11. Hao, J.; Li, X.Y.; Zhang, Y.; Dong, W.K. A reversible bis(salamo)-based fluorescence sensor for selective detection of $\mathrm{Cd}^{2+}$ in water-containing systems and food samples. Materials 2018, 11, 523. [CrossRef]

12. Akine, S.; Hotate, S.; Nabeshima, T. A molecular leverage for helicity control and helix inversion. J. Am. Chem. Soc. 2011, 133, 13868-13871. [CrossRef]

13. Akine, S.; Matsumoto, T.; Sairenji, S.; Nabeshima, T. Synthesis of acyclic tetrakis- and pentakis $\left(\mathrm{N}_{2} \mathrm{O}_{2}\right)$ ligands for single-helical heterometallic complexes with a greater number of winding turns. Supramol. Chem. 2011, 23, 106-112. [CrossRef]

14. Chin, T.K.; Endud, S.; Jamil, S.; Budagumpi, S.; Lintang, H.O. Oxidative dimerization of o-aminophenol by heterogeneous mesoporous material modified with biomimetic salen-type copper(II) complex. Catal. Lett. 2013, 143, 282-288. [CrossRef]

15. Chen, C.Y.; Zhang, J.W.; Zhang, Y.H.; Yang, Z.H.; Wu, H.L.; Pan, G.L.; Bai, Y.C. Gadolinium(III) and dysprosium(III) complexes with a Schiff base bis(N-salicylidene)-3-oxapentane-1,5-diamine: Synthesis, characterization, antioxidation, and DNA-binding studies. J. Coord. Chem. 2015, 68, 1054-1071. [CrossRef] 
16. Wu, H.L.; Wang, H.; Wang, X.L.; Pan, G.L.; Shi, F.R.; Zhang, Y.H.; Bai, Y.C.; Kong, J. V-shaped ligand bis(2-benzimidazolylmethyl)amine containing three copper(II) ternary complexes: Synthesis, structure, DNA binding properties and antioxidant activity. New J. Chem. 2014, 38, 1052-1061. [CrossRef]

17. Zhang, H.; Xu, Y.L.; Wu, H.L.; Aderinto, S.O.; Fan, X.Y. Mono-, bi- and multi-nuclear silver complexes constructed from bis(benzimidazole)-2-oxapropane ligands and methacrylate: Syntheses, crystal structures, DNA-binding properties and antioxidant activities. RSC Adv. 2016, 6, 83697-83708. [CrossRef]

18. Zhang, Y.; Liu, L.Z.; Pan, Y.Q.; Dong, W.K. Structural characterized homotrinuclear Zn ${ }^{\mathrm{II}}$ bis(salamo)-based coordination compound: Hirshfeld surfaces, fluorescent and antimicrobial properties. Crystals 2018, 8, 259. [CrossRef]

19. Gao, L.; Liu, C.; Wang, F.; Dong, W.K. Tetra-, penta- and hexa-coordinated transition metal complexes constructedfrom coumarin-containing $\mathrm{N}_{2} \mathrm{O}_{2}$ ligand. Crystals 2018, 8, 77. [CrossRef]

20. Chai, L.Q.; Li, Y.X.; Chen, L.C.; Zhang, J.Y.; Huang, J.J. Synthesis, X-ray structure, spectroscopic, electrochemical properties and DFT calculation of a bridged dinuclear copper(II) complex. Inorg. Chim. Acta 2016, 444, 193-201. [CrossRef]

21. Dong, W.K.; Ma, J.C.; Zhu, L.C.; Zhang, Y.; Li, X.L. Four new nickel(II) complexes based on an asymmetric salamo-type ligand: Synthesis, structure, solvent effect and electrochemical property. Inorg. Chim. Acta 2016, 445, 140-148. [CrossRef]

22. Ren, Z.L.; Hao, J.; Hao, P.; Dong, X.Y.; Bai, Y.; Dong, W.K. Synthesis, crystal structure, luminescence and electrochemical properties of a salamo-type trinuclear cobalt(II) complex. Z. Naturforschung B 2018, 73, 203-210. [CrossRef]

23. Chai, L.Q.; Tang, L.J.; Chen, L.C.; Huang, J.J. Structural, spectral, electrochemical and DFT studies of two mononuclear manganese(II) and zinc(II) complexes. Polyhedron 2017, 122, 228-240. [CrossRef]

24. Song, X.Q.; Liu, P.P.; Liu, Y.A.; Zhou, J.J.; Wang, X.L. Two dodecanuclear heterometallic $\left[Z_{6} n_{6} n_{6}\right]$ clusters constructed by a multidentate salicylamide salen-like ligand: Synthesis, structure, luminescence and magnetic properties. Dalton Trans. 2016, 45, 8154-8163. [CrossRef]

25. Zhang, L.W.; Li, X.Y.; Kang, Q.P.; Liu, L.Z.; Ma, J.C.; Dong, W.K. Structures and fluorescent and magnetic behaviors of newly synthesized $\mathrm{Ni}^{\mathrm{II}}$ and $\mathrm{Cu}^{\mathrm{II}}$ coordination compounds. Crystals 2018, 8, 173. [CrossRef]

26. Yamashita, A.; Watanabe, A.; Akine, S.; Nabeshima, T.; Nakano, M.; Yamamura, T.; Kajiwara, T. Wheel-shaped $\mathrm{Er}^{\mathrm{III}} \mathrm{Zn}_{3}{ }_{3}$ single-molecule magnet: A macrocyclic approach to designing magnetic anisotropy. Angew. Chem. Int. Ed. 2011, 50, 4016-4019. [CrossRef]

27. Song, X.Q.; Liu, P.P.; Wang, C.Y.; Liu, Y.A.; Liu, W.S.; Zhang, M. Three sandwich-type zinc(II)-lanthanide(III) clusters: Structures, luminescence and magnetic properties. RSC Adv. 2017, 7, 22692-22698. [CrossRef]

28. Zheng, S.S.; Dong, W.K.; Zhang, Y.; Chen, L.; Ding, Y.J. Four salamo-type 3d-4f hetero-bimetallic [Zn $\left.{ }^{\mathrm{II}} \mathrm{Ln}^{\mathrm{III}}\right]$ complexes: Syntheses, crystal structures, and luminescent and magnetic properties. New J. Chem. 2017, 41, 4966-4973. [CrossRef]

29. Zhao, Q.; An, X.X.; Liu, L.Z.; Dong, W.K. Syntheses, luminescences and Hirshfeld surfaces analyses of structurally characterized homo-trinuclear $\mathrm{Zn}^{\mathrm{II}}$ and hetero-pentanuclear $\mathrm{Zn}^{\mathrm{II}}-\mathrm{Ln}^{\mathrm{III}}(\mathrm{Ln}=\mathrm{Eu}, \mathrm{Nd})$ bis(salamo)-like complexes. Inorg. Chim. Acta 2019, 490, 6-15. [CrossRef]

30. Wang, L.; Kang, Q.P.; Hao, J.; Dong, W.K. Two trinuclear cobalt(II) salamo-type complexes: Syntheses, crystal structures, solvent effect and fluorescent properties. Chin. J. Inorg. Chem. 2018, 34, 525-533.

31. Yamamura, M.; Takizawa, H.; Sakamoto, N.; Nabeshima, T. Monomeric and dimeric red/NIR-fluorescent dipyrrin-germanium complexes: Facile monomer-dimer interconversion driven by acid/base additions. Tetrahedron Lett. 2013, 54, 7049-7052. [CrossRef]

32. Peng, Y.D.; Li, X.Y.; Kang, Q.P.; An, G.X.; Zhang, Y.; Dong, W.K. Synthesis and fluorescence properties of asymmetrical salamo-type tetranuclear zinc(II) complex. Crystals 2018, 8, 107. [CrossRef]

33. Dong, X.Y.; Zhao, Q.; Wei, Z.L.; Mu, H.R.; Zhang, H.; Dong, W.K. Synthesis and fluorescence properties of structurally characterized heterobimetalic $\mathrm{Cu}(\mathrm{II})-\mathrm{Na}(\mathrm{I})$ bis(salamo)-based complex bearing square planar, square pyramid and triangular prism geometries of metal centers. Molecules 2018, 23, 1006. [CrossRef]

34. Kang, Q.P.; Li, X.Y.; Zhao, Q.; Ma, J.C.; Dong, W.K. Structurally characterized homotrinuclear salamo-type nickel(II) complexes: Synthesis, solvent effect and fluorescence properties. Appl. Organomet. Chem. 2018, 32, e4379. [CrossRef] 
35. Sakamoto, N.; Ikeda, C.; Yamamura, M.; Nabeshima, T. Structural interconversion and regulation of optical properties of stable hypercoordinate dipyrrin-silicon complexes. J. Am. Chem. Soc. 2011, 133, 4726-4729. [CrossRef]

36. Ikeda, C.; Ueda, S.; Nabeshima, T. Aluminium complexes of $\mathrm{N}_{2} \mathrm{O}_{2}$-type dipyrrins: The first hetero-multinuclear complexes of metallo-dipyrrins with high fluorescence quantum yields. Chem. Commun. 2009, 2544-2546. [CrossRef]

37. Dong, X.Y.; Zhao, Q.; Kang, Q.P.; Mu, H.R.; Zhang, H.; Dong, W.K. Self-assembly of 3d-4f Zn ${ }^{\mathrm{II}}-\mathrm{Ln}^{\mathrm{III}}(\mathrm{Ln}=\mathrm{Ho}$ and Er) bis(salamo)-based complexes: Controlled syntheses, structures and fluorescence properties. Crystals 2018, 8, 230. [CrossRef]

38. Yang, Y.H.; Hao, J.; Dong, Y.J.; Wang, G.; Dong, W.K. Two Znic(II) complexes constructed from a bis(salamo)-type tetraoxime ligand: Syntheses, crystal structures and luminescence properties. Chin. J. Inorg. Chem. 2017, 33, 1280-1292.

39. Hu, J.H.; Sun, Y.; Qi, J.; Li, Q.; Wei, T.B. A new unsymmetrical azine derivative based on coumarin group as dual-modal sensor for $\mathrm{CN}^{-}$and fluorescent “OFF-ON" for $\mathrm{Zn}^{2+}$. Spectrochim. Acta A 2017, 175, $125-133$. [CrossRef]

40. Sun, Y.; Hu, J.H.; Qi, J.; Li, J.B. A highly selective colorimetric and "turn-on" fluorimetric chemosensor for detecting $\mathrm{CN}^{-}$based on unsymmetrical azine derivatives in aqueous media. Spectrochim. Acta A 2016, 167, 101-105. [CrossRef]

41. Akine, S.; Piao, S.J.; Miyashita, M.; Nabeshima, T. Cage-like tris(salen)-type metallocryptand for cooperative guest recognition. Tetrahedron Lett. 2013, 54, 6541-6544. [CrossRef]

42. Nabeshima, T.; Yamamura, M. Cooperative formation and functions of multimetal supramolecular systems. Pure Appl. Chem. 2013, 85, 763-776. [CrossRef]

43. Zhang, H.J.; Chang, J.; Jia, H.R.; Sun, Y.X. Syntheses, supramolecular structures and spectroscopic properties of $\mathrm{Cu}(\mathrm{II})$ and $\mathrm{Ni}(\mathrm{II})$ complexes with Schiff base containing oxime group. Chin. J. Inorg. Chem. 2018, 34, 2261-2270.

44. Jia, H.R.; Li, J.; Sun, Y.X.; Guo, J.Q.; Yu, B.; Wen, N.; Xu, L. Two supramolecular cobalt(II) complexes: Syntheses, crystal structures, spectroscopic behaviors, and counter anion effects. Crystals 2017, 7, 247.

45. Zhou, L.; Hu, Q.; Chai, L.Q.; Mao, K.H.; Zhang, H.S. X-ray characterization, spectroscopic, DFT calculations and Hirshfeld surface analysis of two 3-D supramolecular mononuclear zinc(II) and trinuclear copper(II) complexes. Polyhedron 2019, 158, 102-116. [CrossRef]

46. Chang, J.; Zhang, H.J.; Jia, H.R.; Sun, Y.X. Binuclear nickel(II) and zinc(II) complexes based on 2-amino-3-hydroxy-pyridine Schiff base: Syntheses, supramolecular structures and spectral properties. Chin. J. Inorg. Chem. 2018, 34, 2097-2107.

47. Spackman, M.A.; McKinnon, J.J.; Jayatilaka, D. Electrostatic potentials mapped on Hirshfeld surfaces provide direct insight into intermolecular interactions in crystals. Cryst. Eng. Commun 2008, 10, 377-388. [CrossRef]

48. An, X.X.; Zhao, Q.; Mu, H.R.; Dong, W.K. A new half-salamo-based homo-trinuclear nickel(II) complex: Crystal structure, Hirshfeld surface analysis, and fluorescence properties. Crystals 2019, 9, 101. [CrossRef]

49. Dong, X.Y.; Kang, Q.P.; Li, X.Y.; Ma, J.C.; Dong, W.K. Structurally characterized solvent-induced homotrinuclear cobalt(II) $\mathrm{N}_{2} \mathrm{O}_{2}$-donor bisoxime-type complexes. Crystals 2018, 8, 139. [CrossRef]

50. Dong, W.K.; Lan, P.F.; Zhou, W.M.; Zhang, Y. Salamo-type trinuclear and tetranuclear cobalt(II) complexes based on a new asymmetry salamo-type ligand: Syntheses, crystal structures and fluorescence properties. J. Coord. Chem. 2016, 65, 1272-1283. [CrossRef]

51. Dong, W.K.; Zhang, J.T.; Dong, Y.J.; Zhang, Y.; Wang, Z.K. Construction of mononuclear copper(II) and trinuclear cobalt(II) complexes based on asymmetric salamo-type ligands. Z. Anorg. Allg. Chem. 2016, 642, 189-196. [CrossRef]

52. Dong, W.K.; Zheng, S.S.; Zhang, J.T.; Zhang, Y.; Sun, Y.X. Luminescent properties of heterotrinuclear 3d-4f complexes constructed from a naphthalenediol-based acyclic bis(salamo)-type ligand. Spectrochim. Acta A 2017, 184, 141-150. [CrossRef]

(C) 2019 by the authors. Licensee MDPI, Basel, Switzerland. This article is an open access article distributed under the terms and conditions of the Creative Commons Attribution (CC BY) license (http://creativecommons.org/licenses/by/4.0/). 